ARTICLE

\title{
Antibacterial activity in three Chaetoceros microalgae species cultures by using antibiotics
}

\author{
Actividad antibacteriana en cultivos de tres especies de microalgas Chaetoceros \\ utilizando antibióticos
}

\section{Yira D. Tapia-Gallardo ${ }^{1}$, Miguel A. del Río-Portilla ${ }^{(1}{ }^{1}$, Ceres A. Molina-Cárdenas ${ }^{1}{ }^{1}$ and M. del Pilar Sánchez-Saavedra ${ }^{1 *}$}

\author{
${ }^{1}$ Departamento de Acuicultura, Centro de Investigación Científica y de Educación Superior de Ensenada (CICESE), Carretera Tijuana- \\ Ensenada 3918, Zona Playitas, CP 22860, Ensenada, Baja California, México \\ *Corresponding author: psanchez@cicese.mx
}

\begin{abstract}
Resumen.- Las diatomeas, como Chaetoceros, crecen en una relación mutualista con bacterias. Sin embargo, en algunos casos es necesario que proliferen en cultivos libres de bacterias. Para reducir la carga de bacterias se usan antibióticos y en determinadas ocasiones se requiere utilizar una mezcla con más de un antibiótico. El objetivo de este trabajo fue obtener un protocolo rápido y efectivo para reducir la carga bacteriana y evaluar la respuesta en crecimiento de tres especies de Chaetoceros de importancia acuícola. Se utilizaron antibióticos individuales y en mezcla. El crecimiento de microalgas y bacterias heterotróficas fue evaluado. Los parámetros de crecimiento muestran mayor concentración para C. muelleri $\left(3,15 \times 10^{6}\right.$ céls $\left.\mathrm{mL}^{-1}\right)$ y bajos valores para $C$. calcitrans $\left(2,98 \times 10^{6}\right.$ céls $\left.\mathrm{mL}^{-1}\right)$. La mayor tasa de crecimiento fue para $C$. calcitrans $(0,77$ divisiones por día) y los menores valores fueron para Chaetoceros sp. ( 0,60 divisiones por día). Los parámetros de crecimiento en bacterias heterotróficas muestran una carga bacteriana significativamente mayor para Chaetoceros sp. $\left(19,16 \times 10^{6}\right.$ UFC (UFC, unidades formadoras de colonias) $\mathrm{mL}^{-1}$ ) y los menores valores fueron para C. calcitrans $\left(12,23 \times 10^{6} \mathrm{UFC} \mathrm{mL}^{-1}\right)$. La tasa de crecimiento de las bacterias heterotróficas presentes en los cultivos de Chaetoceros fue similar entre las tres especies estudiadas. La estreptomicina ${ }^{\circledR}$ y el sulfato $\mathrm{G}^{\circledR} 1^{\circledR}$ producen reducción parcial de la carga bacteriana. El tratamiento más efectivo para las tres especies fue uso de una mezcla de antibióticos compuesta de ampicilina ${ }^{\circledR}$ $\left(250 \mu \mathrm{g} \mathrm{mL}^{-1}\right)$, kanamicina ${ }^{\circledast}\left(200 \mu \mathrm{g} \mathrm{mL}^{-1}\right)$, neomicina ${ }^{\circledast}\left(50 \mu \mathrm{g} \mathrm{mL}^{-1}\right)$ y estreptomicina ${ }^{\circledR}\left(100 \mu \mathrm{g} \mathrm{mL}^{-1}\right)$ durante tres días. La mezcla preparada con alta concentración de antibióticos produjo una reducción de la carga bacteriana (100\%) por tres días, sin embargo, también redujo significativamente el crecimiento (10 a 30\%) de las tres especies de Chaetoceros.
\end{abstract}

Palabras clave: Carga bacteriana, Chaetoceros spp., antibióticos, cultivos axénicos, bacterias heterotróficas

\begin{abstract}
Diatoms, such as Chaetoceros, grow in a mutualistic relationship with bacteria. However, in some cases, it is necessary to grow them in bacteria-free cultures. To reduce bacterial load, antibiotics are used, and on certain occasions it is necessary to use a mixture with more than one antibiotic. This work aimed to obtain a quick and effective protocol to reduce the bacterial load and evaluate the response of three Chaetoceros species with aquacultural importance. Single and mix antibiotics were used. Microalgal and bacterial growth was measured. The growth parameters for diatoms showed that the significantly highest cell concentration was for $C$. muelleri $\left(3.15 \times 10^{6}\right.$ cells mL $\left.\mathrm{L}^{-1}\right)$ and the lowest values to $C$. calcitrans $\left(2.98 \times 10^{6}\right.$ cells $\left.\mathrm{mL}^{-1}\right)$. The significantly highest growth rate was for $C$. calcitrans ( 0.77 divisions per day), and the lowest values for Chaetoceros sp. ( 0.60 divisions per day). The growth parameters for heterotrophic bacteria showed that the significantly highest bacterial load was for Chaetoceros sp. (19.16 x $10^{6} \mathrm{CFU}$ (Colony-Forming Units) $\left.\mathrm{mL}^{-1}\right)$ and the lowest values were for C. calcitrans $\left(12.23 \times 10^{6} \mathrm{CFU} \mathrm{mL}^{-1}\right)$. The growth rate of the heterotrophic bacteria present in Chaetoceros cultures was similar among the three studied species. Streptomycin ${ }^{\circledR}$ and sulfate G41 ${ }^{\circledR}$ produced a partial reduction of bacterial load. The most effective treatment for all three species was the use of an antibiotic mix composed of ampicillin $^{\circledast}\left(250 \mu \mathrm{g} \mathrm{mL}^{-1}\right)$, kanamycin ${ }^{\circledast}\left(200 \mu \mathrm{g} \mathrm{mL}^{-1}\right)$, neomycin ${ }^{\circledast}\left(50 \mu \mathrm{g} \mathrm{m}^{-1}\right)$, and streptomycin ${ }^{\circledast}\left(100 \mu \mathrm{gL}^{-1}\right)$ for three days. The mix prepared with the highest antibiotic concentration produced a reduction of bacteria (100\%) for three days; however, it also induced a significant reduction of the growth of the three Chaetoceros species.
\end{abstract}

Key words: Bacterial load, Chaetoceros spp., antibiotics, axenic cultures, heterotrophic bacteria

\section{INTRODUCTION}

Diatoms are highly diverse photosynthetic organisms characterized by its silica frustules (Leynaert et al. 2018). They are cosmopolite organisms that can be found in marine and seawater environments and are responsible for $20-25 \%$ of global primary production (Bozarth et al. 2009). Among all known diatoms, Chaetoceros is a primarily marine genus and one of the most abundant, reaching almost 228 described species (Guiry \& Guiry 2021). Species belonging to this genus, such as Chaetoceros muelleri (Kumaran et al. 2017), Chaetoceros calcitrans (Milagros et al. 2018), and Chaetoceros sp. (Sánchez-Saavedra \& Voltolina 1995, 2006), have a great importance to aquaculture industry due to their biochemical composition, making them an excellent source of feed to fish, crustaceans, and mollusk larvae. The strain of Chaetoceros sp. (CHX1) was isolated 
in 1988 from Todos Santos Bay at Baja California, Mexico (Trujillo-Valle 1993). This strain has a high potential to be used on aquaculture due its high population growth rates and biochemical composition (Sánchez-Saavedra \& Voltolina 1995, 2001, 2006). The species identification has remained uncertain, but it seems to be a strain of Chaetoceros gracilis (Tapia-Gallardo 2019).

Diatoms coexist with other microalgal species and bacteria. In fact, exopolysaccharides (EPS) produced by diatoms are utilized by heterotrophic bacteria as their source of organic carbon (Duff et al. 1996, Johansson et al. 2019, Koedooder et al. 2019). Thus, diatom cultures commonly have a high content of heterotrophic bacteria, which may have deleterious effects on growth performance, nutritional quality, and safety of the cells if they are used as feed in aquaculture (Molina-Cárdenas et al. 2016). Bacteria may even cause interference in biotechnology, pharmaceutical, biochemical, physiological, taxonomic, and genetic studies, such as the production of compounds with biological activity or genome of diatom species (Vu et al. 2018). To reduce the negative impact of high bacterial load it has been recommended to use axenic cultures (i.e., free from undesirable contaminants like bacteria, fungi) (Cho et al. 2013). However, the production and maintenance of axenic cultures is often difficult and a time-consuming task (Bruckner \& Kroth 2009, Lee et al. 2015, Zakharova et al. 2020).

Several physical and chemical strategies, involving centrifugation, selective growth media, UV irradiation, filtration, sonication, dilution, purification by micropipette, vortexing, application of mixtures and doses of antibiotics (Andersen \& Kawachi 2005, Bruckner \& Kroth 2009) are frequently used to control or reduce the bacterial load in microalgal cultures (Sena et al. 2011, Molina et al. 2019). In some cases, the use of only one technique is not enough to reduce the bacterial load and the application of two or more techniques is required. Additionally, specialized equipment and trained personnel are required (Ishii et al. 2018).

Some efforts to obtain axenic cultures of the diatoms Nitzschia capitellata and Halamphora coffeiformis (Guiry \& Guiry 2021) have been performed by pipetting, seeding in agar, use of detergents, phenol solutions, and UV radiation. The results were not satisfactory, and the diatom cultures were still contaminated with bacteria and the microalgae cells were damaged (Jones et al. 1973). In a study performed by Nagai et al. (1998) the application of washes with a sieve and antibiotic treatment was effective to obtain axenic cultures of the diatom Coscinodiscus wailesii. Recently Ishii et al. (2018) reported a method to obtain axenic cultures of several microalgal species by sieving and washing resting stage cells. The method was successful to remove bacteria from several diatom species, but the authors affirm that the protocol is useful to species that have endogenous resting spores and cannot be applied to other diatoms.

Although the use of antibiotics is the most common technique employed to reduce bacterial load (Choi et al. 2008, Han et al. 2014), effectiveness of bacteria removal from the microalgae cultures can depend on the mechanism of action of the antibiotics used and the bacteria associated to diatom cultures. Thus, the selection is a critical issue when a protocol to reduce bacterial load in diatom cultures has to be decided, in order to remove bacteria and avoid deleterious effects on microalgae (Han et al. 2014). Additionally, the response is species-specific and protocols should thus be adapted to each microalgal species.

This work aimed to obtain a quick and effective protocol to reduce bacterial load and evaluate growth response of Chaetoceros muelleri, Chaetoceros calcitrans, and Chaetoceros sp., which are widely used in aquaculture facilities due to their good growth performance, nutritional value and for being organisms of interest for genetic studies.

\section{MATERIALS AND METHODS}

\section{Diatoms Cultures}

Chaetoceros muelleri (CHM1), Chaetoceros calcitrans (CHC1) and Chaetoceros sp. (CHX1) strains were provided by the microalgal collection of CICESE, Department of Aquaculture. Cultures of each Chaetoceros were maintained in batch using triplicate sets in $125 \mathrm{~mL}$ Erlenmeyer flasks with $100 \mathrm{~mL}$ "f” media (Guillard \& Ryther 1962). Light was provided by fluorescent lamps at $50 \mu \mathrm{mol} \mathrm{m} \mathrm{m}^{-2} \mathrm{~s}^{-1}, 21$ $\pm 1{ }^{\circ} \mathrm{C}$ and salinity of 35 . To characterize culture growth, cell concentration and heterotrophic bacteria were measured daily.

\section{Microalgae Counts}

The cell concentration of each strain of Chaetoceros cultures was measured by direct counts with a hemocytometer (Bright Line, Hausser Scientific, USA). The cell concentrations were $\log _{2}$-transformed to determine the growth rate $(\mu \mathrm{m}$ : divisions per day) of each strain of Chaetoceros, according to the following equation, as described by Fogg \& Thake (1987).

$$
\mu m=\left[\log _{2}\left(N_{2}\right)-\log _{2}\left(N_{1}\right)\right] /\left(t_{2}-t_{1}\right)
$$

where, $N_{1}$ and $N_{2}$ are the cell concentrations at the initial day $\left(t_{1}\right)$ and final day $\left(t_{2}\right)$ respectively, measured during the exponential growth. 


\section{BACTERIAL COUNTS}

The concentration of heterotrophic bacteria in the cultures of each strain of Chaetoceros was obtained daily. The content of bacteria was estimated from the culture medium and dilutions of $10^{-3}$ were made for each case. Dilutions for bacterial counts were carried out using a physiological serum $\left(9 \mathrm{~g}\right.$ of $\left.\mathrm{NaCl} \mathrm{L}^{-1}\right)$, and, for each dilution, $0.1 \mathrm{ml}$ was used to inoculate a Petri dish with $20 \mathrm{~mL}$ of the ZoBell medium (ZoBell 1941). Petri dishes were incubated in a mini VWR incubator at $31{ }^{\circ} \mathrm{C}$ for $48 \mathrm{~h}$. Bacterial load was expressed as colony-forming units per milliliter $\left(\mathrm{CFU} \mathrm{mL} \mathrm{mL}^{-1}\right)$ (Gerhardt et al. 1981) and was used to determine the growth rate of bacteria $(\mu \mathrm{b})$ according to equation 1 , this growth model was used for bacteria with $\log _{2}$ because they have binary division.

\section{BACTERIAL LOAD REDUCTION ASSAYS}

The three Chaetoceros species were maintained as monospecific batch cultures in $10 \mathrm{~mL}$ glass tubes with $5 \mathrm{~mL}$ "f" media (Guillard \& Ryther 1962). The culture conditions were the same as described for diatom culture.

To decrease bacterial load of the cultures, two assays were carried out. The first assay included 5 treatments (Table 1) to select the best protocol for reducing bacterial load while maintaining microalgal growth. The second assay considered three treatments (Table 1) to see the effect of antibiotics on bacterial load while maintaining microalgal growth. All treatments were applied for $48 \mathrm{~h}$.

The first assay consisted of:

1) Treatment 1: The cells were concentrated by centrifugation at $2,232 \mathrm{~g}$ for $10 \mathrm{~min}$ at $4{ }^{\circ} \mathrm{C}$ and then, cell package of each culture was washed with sterile seawater.

2) Treatment 2: The cells were concentrated and washed as described for treatment 1 . The collected cell package was suspended in $5 \mathrm{~mL}$ of " $\mathrm{f}$ " media with the addition of $75 \mu \mathrm{g}$ $\mathrm{mL}^{-1}$ of streptomycin $\AA$ (SIGMA).

3) Treatment 3: The cells were concentrated and washed as described for treatment 1 . The collected cell package was suspended in $5 \mathrm{~mL}$ of "f" media with the addition of $250 \mu \mathrm{g}$ $\mathrm{mL}^{-1}$ of sulfate $\mathrm{G} 41{ }^{\circledR}$ (SIGMA).

4) Treatment 4: The cells were concentrated and washed as described for treatment 1 . The collected cell package was suspended in $5 \mathrm{~mL}$ of " $\mathrm{f}$ " media with the addition of an antibiotic mix composed of ampicillin ${ }^{\circledR}$ (SIGMA) 250 $\mu \mathrm{g} \mathrm{mL} L^{-1}$, kanamycin ${ }^{\circledR}$ (SIGMA) $200 \mu \mathrm{g} \mathrm{mL}^{-1}$, neomycin ${ }^{\circledR}$ (SIGMA) $50 \mu \mathrm{g} \mathrm{mL}^{-1}$, and streptomycin ${ }^{\circledR}$ (SIGMA) 100 $\mu \mathrm{g} \mathrm{mL}^{-1}$.

5) Treatment 5: Control of the treatments, $5 \mathrm{~mL}$ of each culture was maintained with "f" media in $10 \mathrm{~mL}$ glass tubes in triplicates and without the application of any of the four treatments described above.

A second assay was performed based on the previous results obtained from the first assay (Treatment 4), to determine whether a higher antibiotic mix concentration could reduce the bacterial count without damaging the microalgae (Table 1).

A) Treatment A consisted of washing the cell package as described for treatment 1 . The collected cell package was suspended in $5 \mathrm{~mL}$ of "f" media, with the addition of the antibiotic mix composed of ampicillin ${ }^{\circledR} 250 \mu \mathrm{g} \mathrm{mL}^{-1}$, kanamycin ${ }^{\circledR} 200 \mu \mathrm{g} \mathrm{mL}^{-1}$, neomycin ${ }^{\circledR} 50 \mu \mathrm{g} \mathrm{mL}^{-1}$, and streptomycin ${ }^{\circledR} 100 \mu \mathrm{g} \mathrm{mL}^{-1}$.

B) Treatment B consisted of washing the cell package as described for treatment 1 . The collected cell package was suspended in $5 \mathrm{~mL}$ of " $\mathrm{f}$ " media with the addition of an antibiotic mix composed of ampicillin ${ }^{\circledR} 500 \mu \mathrm{g} \mathrm{mL}^{-1}$,

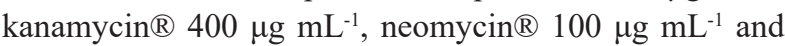
streptomycin ${ }^{\circledR} 200 \mu \mathrm{g} \mathrm{mL}^{-1}$.

C) Treatment $\mathrm{C}$ as control of the treatments, $5 \mathrm{~mL}$ of each culture was maintained with " $\mathrm{f}$ " media in $10 \mathrm{~mL}$ glass tubes in triplicates and without the two treatments described above.

\section{Statistical ANALYSIS}

All data were tested for homoscedasticity and normality. To analyze the effects of antibiotics on three Chaetoceros species a student's t-test was applied to initial and final cell densities. A one-way ANOVA was used to evaluate the differences in cell concentration to each Chaetoceros strain maintained with different treatments. The same analysis was used to obtain the differences in heterotrophic bacteria content among treatments. When significant differences were detected, Tukey a posteriori test was used. The significance level for all the analyses was set to $P<0.05$. The figures were performed using SigmaPlot 10 software (SigmaPlot 2021). 
Table 1. Treatments used to reduce the bacterial load in cultures of three Chaetoceros species / Tratamientos usados para reducir la carga bacteriana en cultivos de tres especies de Chaetoceros

\begin{tabular}{|c|c|c|c|}
\hline & $\begin{array}{l}\text { Wash and } \\
\text { centrifugation }\end{array}$ & Antibiotic & $\begin{array}{c}\text { Concentration } \\
\left(\mu \mathrm{g} \mathrm{mL}^{-1}\right)\end{array}$ \\
\hline \multicolumn{4}{|c|}{ Assay 1} \\
\hline 1 & $2232 \mathrm{~g}$ for $10 \mathrm{~min}$ & None & None \\
\hline 2 & $2232 \mathrm{~g}$ for $10 \mathrm{~min}$ & Streptomycin $®$ & 75 \\
\hline 3 & $2232 \mathrm{~g}$ for $10 \mathrm{~min}$ & Sulfate $G 41 \circledR$ & 250 \\
\hline \multirow[t]{4}{*}{4} & $2232 \mathrm{~g}$ for $10 \mathrm{~min}$ & Ampicillin $®$ & 250 \\
\hline & & Kanamycin ${ }^{\circledR}$ & 200 \\
\hline & & Neomycin $(\mathbb{B}$ & 50 \\
\hline & & Streptomycin $₫$ & 100 \\
\hline 5 & None & None & None \\
\hline \multicolumn{4}{|c|}{ Assay 2} \\
\hline \multirow[t]{4}{*}{ A } & $2232 \mathrm{~g}$ for $10 \mathrm{~min}$ & Ampicillin ${ }$ & 250 \\
\hline & & Kanamycin ${ }^{\circledR}$ & 200 \\
\hline & & Neomycin® & 50 \\
\hline & & Streptomycin $₫$ & 100 \\
\hline \multirow[t]{4}{*}{ B } & 2232 for $10 \mathrm{~min}$ & Ampicillin $®$ & 500 \\
\hline & & Kanamycin ${ }^{\circledR}$ & 400 \\
\hline & & Neomycin $\mathbb{B}$ & 100 \\
\hline & & Streptomycin $®$ & 200 \\
\hline $\mathrm{C}$ & None & None & None \\
\hline
\end{tabular}

\section{RESULTS}

\section{MicroalgaE AND BACTERIAL GROWTH}

The growth curve shows that $C$. muelleri and C. calcitrans had an exponential growth phase until day 4, after which the stationary-growth phase began, and during day 7, a decrease in cell concentration was evaluated. Chaetoceros sp. maintain their exponential growth from day 2 to day 7 (Fig. 1).

The growth parameters for diatoms show that the significantly highest cell concentration $(P<0.05)$ was observed for $C$. muelleri $\left(3.15 \times 10^{6}\right.$ cells $\left.\mathrm{mL}^{-1}\right)$ and the lowest values for $C$. calcitrans $\left(2.98 \times 10^{6}\right.$ cells $\mathrm{mL}^{-1}$; Table 1). The significantly highest growth rate was for $C$. calcitrans ( 0.77 divisions per day) and the lowest values
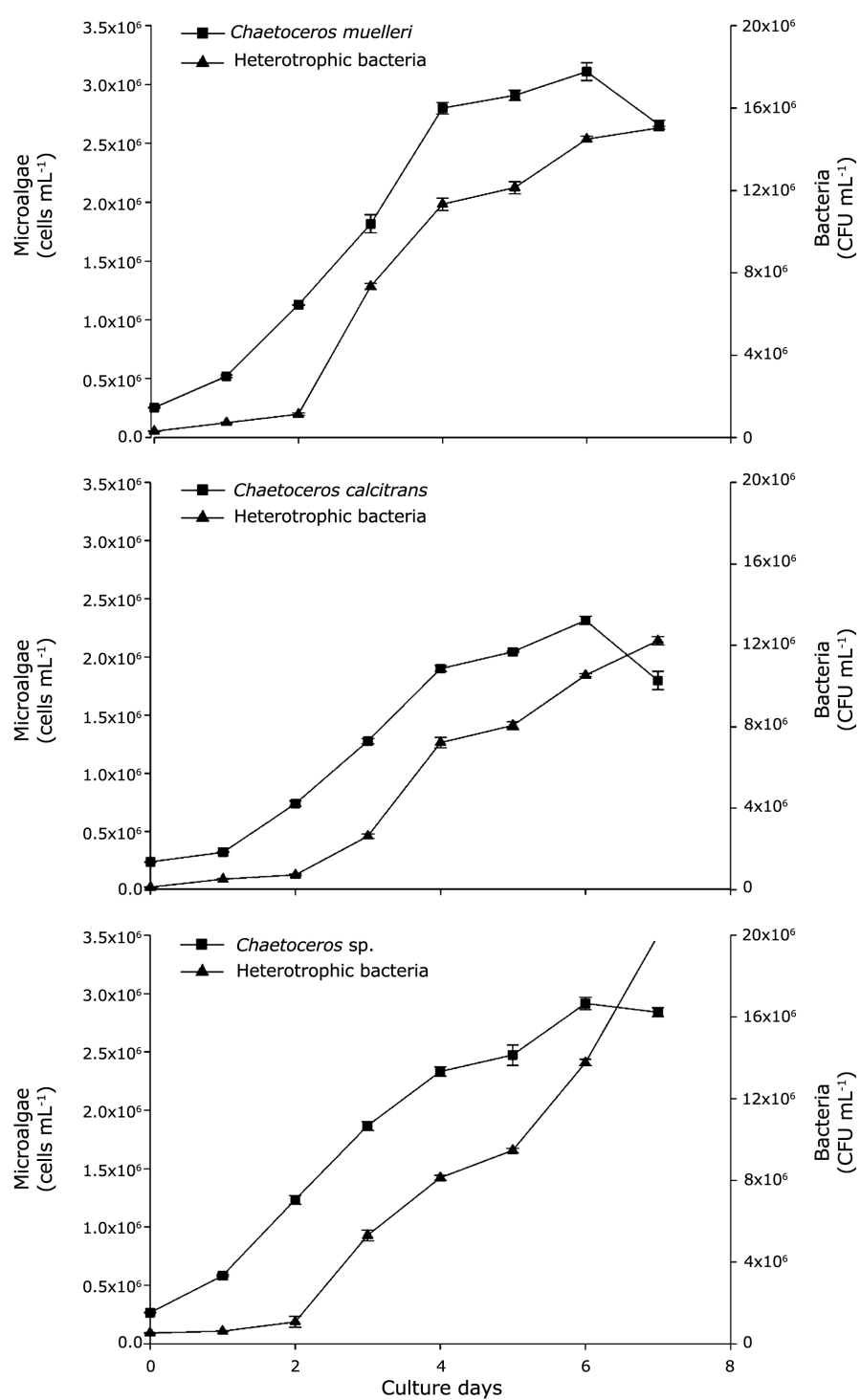

Figure 1. Mean values and standard deviation of cell concentration and heterotrophic bacterial load of monospecific and non-axenic batch cultures of Chaetoceros muelleri, C. calcitrans and Chaetoceros sp. / Valores promedio y desviación estándar de la concentración de células y carga de bacterias heterotróficas de cultivos en lote monoespecíficos, no axénicos de Chaetoceros muelleri, C. calcitrans y Chaetoceros sp. 
for Chaetoceros sp. ( 0.60 divisions per day; $P<0.05)$. The growth parameters for heterotrophic bacteria show that the significantly highest bacterial load was for Chaetoceros sp. $\left(19.16 \times 10^{6} \mathrm{CFU} \mathrm{mL} \mathrm{mL}^{-1}\right)$ and the lowest values for $C$. calcitrans $\left(12.23 \times 10^{6} \mathrm{CFU} \mathrm{mL}^{-1} ; P<0.05\right)$. The growth rate of the heterotrophic bacteria was similar between the three Chaetoceros species $(P>0.05$; Table 2$)$.

\section{BACTERIAL LOAD REDUCTION ASSAYS}

In the first assay, for $C$. muelleri cultures maintained with the different treatments to decrease bacterial load, the results showed that the final cell concentration (FCC) was significantly higher when washed with sterile water + sulfate G41® $\left(\mathrm{T} 3: 3.36 \times 10^{6}\right.$ cells $\left.\mathrm{mL}^{-1}\right)$. Meanwhile, the lowest cell concentration was for the control without antibiotic treatment (control) (T5: $2.43 \times 10^{6}$ cells $\mathrm{mL}^{-1} ; P$ $<0.05$; Table 3 ). The treatment that significantly reduced the heterotrophic bacterial load corresponded to washing with sterile seawater + antibiotic mix (T4: $0.08 \times 10^{6} \mathrm{CFU}$ $\left.\mathrm{mL}^{-1}\right)$, meanwhile, the highest values were for the control treatment (T5: $11.74 \times 10^{6} \mathrm{CFU} \mathrm{mL}^{-1} ; P<0.05$; Table 3).

For C. calcitrans cultures, the final cell concentration (FCC) was significantly higher for washing with sterile seawater + streptomycin ${ }^{\circledR}(\mathrm{T} 2)$ and washing with sterile seawater + antibiotic mix (T4) (both with $2.78 \times 10^{6}$ cells $\left.\mathrm{mL}^{-1}\right)$ and washed with sterile seawater + sulfate G41 ${ }^{\circledR}$ (T3: $2.86 \times 10^{6}$ cells $\mathrm{mL}^{-1}$ ); meanwhile the lowest cell concentration was for the control without antibiotic treatment (control) (T5: $2.33 \times 10^{6}$ cells $\mathrm{mL}^{-1} ; P<0.05$; Table 3 ). The treatment that significantly reduced the heterotrophic bacterial load corresponded to washing with sterile seawater + antibiotic $\operatorname{mix}\left(\mathrm{T} 4: 0.06 \times 10^{6} \mathrm{CFU}\right.$ $\left.\mathrm{mL}^{-1}\right)$, meanwhile, the highest values were for the control treatment (T5: $\left.8.60 \times 10^{6} \mathrm{CFU} \mathrm{mL}^{-1}\right)(P<0.05)$ (Table 3).

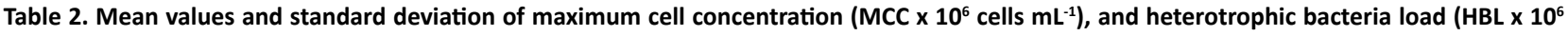
CFU $\mathrm{mL}^{-1}$ ), growth rate of microalgae ( $\mu \mathrm{m}$, divisions per day) and growth rate of heterotrophic bacteria ( $\mu \mathrm{b}$, divisions per day) of Chaetoceros muelleri, $\mathbf{C}$. calcitrans and Chaetoceros sp. of monospecific batch cultures (first assay) / Valores promedio y desviación estándar de la concentración máxima de células ( $\mathrm{MCC} \times 10^{6}$ céls $\mathrm{mL}^{-1}$ ) y carga de bacterias heterotróficas ( $\mathrm{HBL} \times 10^{6} \mathrm{UFC} \mathrm{mL}^{-1}$ ), tasa de crecimiento de microalgas ( $\mu \mathrm{m}$, divisiones por día) y bacterias heterotróficas ( $\mu \mathrm{b}$, divisiones por día) de Chaetoceros muelleri, $C$. calcitrans y Chaetoceros sp. de cultivos monoespecíficos en lotes (primer ensayo)

\begin{tabular}{lccccc}
\hline \multirow{2}{*}{ Species } & \multicolumn{4}{c}{ Growth parameters } \\
\cline { 2 - 3 } \cline { 5 - 6 } & \multicolumn{2}{c}{ MCC } & $\mu_{\mathrm{m}}$ & & \multicolumn{2}{c}{ Bacteria } \\
\cline { 2 - 3 } \cline { 5 - 6 } C. muelleri & $3.15 \pm 0.04 \mathrm{a}$ & $0.73 \pm 0.01 \mathrm{~b}$ & & $16.15 \pm 0.13 \mathrm{~b}$ & $0.95 \pm 0.01 \mathrm{a}$ \\
C. calcitrans & $2.34 \pm 0.01 \mathrm{c}$ & $0.77 \pm 0.01 \mathrm{a}$ & & $12.23 \pm 0.20 \mathrm{c}$ & $0.98 \pm 0.04 \mathrm{a}$ \\
Chaetoceros sp. & $2.98 \pm 0.05 \mathrm{~b}$ & $0.60 \pm 0.01 \mathrm{c}$ & & $19.96 \pm 0.15 \mathrm{a}$ & $0.93 \pm 0.02 \mathrm{a}$ \\
\hline
\end{tabular}

Different letters denote significant differences (one-way ANOVA $P<0.05: \mathrm{a}>\mathrm{b}>\mathrm{c}$ )

Table 3. Mean values and standard deviation of initial cell concentration (ICC $\times 10^{6}$ cells $\mathrm{mL}^{-1}$ ), final cell concentration (FCC $\times 10^{6}$ cells $\mathrm{mL}^{-1}$ ) and heterotrophic bacteria load ( $\mathrm{HBL} \times 10^{6} \mathrm{CFU} \mathrm{mL^{-1 }}$ ) of Chaetoceros muelleri, $\mathrm{C}$. calcitrans and Chaetoceros sp. of monospecific batch cultures with different treatments (first assay) / Valores promedio y desviación estándar de la concentración celular inicial (ICC $\times 10^{6}$ céls $\mathrm{mL}^{-1}$ ), concentración

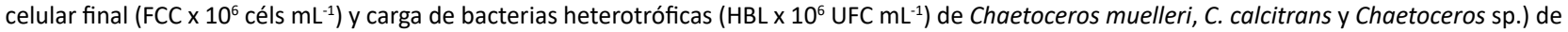
cultivos monoespecíficos en lotes con diferentes tratamientos (primer ensayo)

\begin{tabular}{lccccc}
\hline \multicolumn{1}{c}{ Species } & T1 & T2 & T3 & T4 & T5 \\
\hline C. muelleri & & & & & \\
ICC & $2.21 \pm 0.04 \mathrm{a}$ & $2.17 \pm 0.07 \mathrm{a}$ & $2.08 \pm 0.05 \mathrm{a}$ & $2.07 \pm 0.07 \mathrm{a}$ & $2.35 \pm 0.17 \mathrm{a}$ \\
FCC & $2.57 \pm 0.67 \mathrm{~b}$ & $3.06 \pm 0.08 \mathrm{a}$ & $3.36 \pm 0.09 \mathrm{a}$ & $2.77 \pm 0.03 \mathrm{a}$ & $2.43 \pm 0.02 \mathrm{~b}$ \\
HBL & $5.58 \pm 0.37 \mathrm{~b}$ & $11.40 \pm 0.56 \mathrm{a}$ & $9.60 \pm 0.28 \mathrm{ab}$ & $0.08 \pm 0.02 \mathrm{c}$ & $11.74 \pm 0.48 \mathrm{a}$ \\
C. calcitrans & & & & & \\
ICC & $2.03 \pm 0.08 \mathrm{a}$ & $1.94 \pm 0.08 \mathrm{a}$ & $2.01 \pm 0.01 \mathrm{a}$ & $1.98 \pm 0.01 \mathrm{a}$ & $2.11 \pm 0.01 \mathrm{a}$ \\
FCC & $2.41 \pm 0.01 \mathrm{~b}$ & $2.78 \pm 0.05 \mathrm{a}$ & $2.86 \pm 0.01 \mathrm{a}$ & $2.78 \pm 0.05 \mathrm{a}$ & $2.33 \pm 0.01 \mathrm{~b}$ \\
HBL & $4.40 \pm 0.14 \mathrm{~b}$ & $7.10 \pm 0.14 \mathrm{a}$ & $5.70 \pm 0.14 \mathrm{ab}$ & $0.06 \pm 0.00 \mathrm{c}$ & $8.60 \pm 0.14 \mathrm{a}$ \\
Chaetoceros sp. & & & & & \\
ICC & $2.05 \pm 0.07 \mathrm{a}$ & $2.07 \pm 0.07 \mathrm{a}$ & $2.10 \pm 0.03 \mathrm{a}$ & $2.11 \pm 0.01 \mathrm{a}$ & $2.17 \pm 0.07 \mathrm{a}$ \\
FCC & $2.61 \pm 0.01 \mathrm{~b}$ & $2.81 \pm 0.01 \mathrm{a}$ & $2.68 \pm 0.01 \mathrm{a}$ & $2.91 \pm 0.02 \mathrm{a}$ & $2.45 \pm 0.03 \mathrm{~b}$ \\
HBL & $7.57 \pm 0.10 \mathrm{~b}$ & $13.26 \pm 0.09 \mathrm{a}$ & $11.06 \pm 0.09 \mathrm{ab}$ & $0.13 \pm 0.01 \mathrm{c}$ & $15.30 \pm 0.14 \mathrm{a}$ \\
\hline
\end{tabular}

$\mathrm{T} 1$, washed with sterile seawater. $\mathrm{T} 2$, washed with sterile seawater + streptomycin $囚 . \mathrm{T} 3$, washed with sterile seawater + sulfate $G 41 \circledR$. T4, washed with sterile seawater + antibiotic mix. T5, control without treatment addition. Different letters denote significant differences (one-way ANOVA $P<0.05: \mathrm{a}>\mathrm{b}>\mathrm{c}$ ) 
For Chaetoceros sp. cultures, FCC was significantly higher for washing with sterile seawater + antibiotic mix (T4: $2.91 \times 10^{6}$ cells $\mathrm{mL}^{-1}$ ) and washing with sterile seawater + antibiotic mix (T4: $2.86 \times 10^{6}$ cells $\mathrm{mL}^{-1}$ ); meanwhile, the lowest cell concentration was for the control without antibiotic treatment (control) (T5: $2.45 \times 10^{6}$ cells $\mathrm{mL}^{-}$ 1; $P<0.05$; Table 3 ). The treatment that significantly reduced the heterotrophic bacteria load was for washing with sterile seawater + antibiotic mix $\left(\mathrm{T} 4: 0.13 \times 10^{6} \mathrm{CFU}\right.$ $\left.\mathrm{mL}^{-1}\right)$; meanwhile, the highest values were for the control treatment (T5: $15.30 \times 10^{6} \mathrm{CFU} \mathrm{mL}^{-1} ; P<0.05$; Table 3).
For the second assay, the antibiotic mix used to decrease the bacterial load on the diatom cultures showed that the significantly highest cell concentration corresponded to control treatment of the three strains ( $P<0.05$; Fig. 2). The control treatment increased the cell concentration throughout the culture time until day 5, after which the cell concentration decreased in the three diatom strains. The heterotrophic bacterial load increased significantly $(P<$ 0.05 ) throughout the culture time on the control treatment. a)

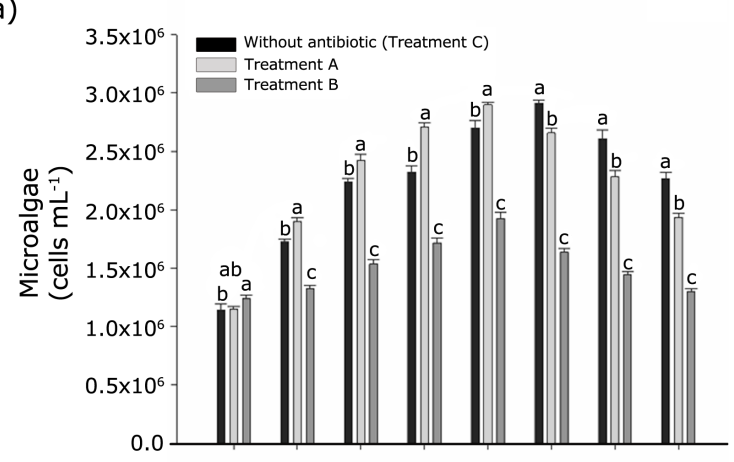

c)

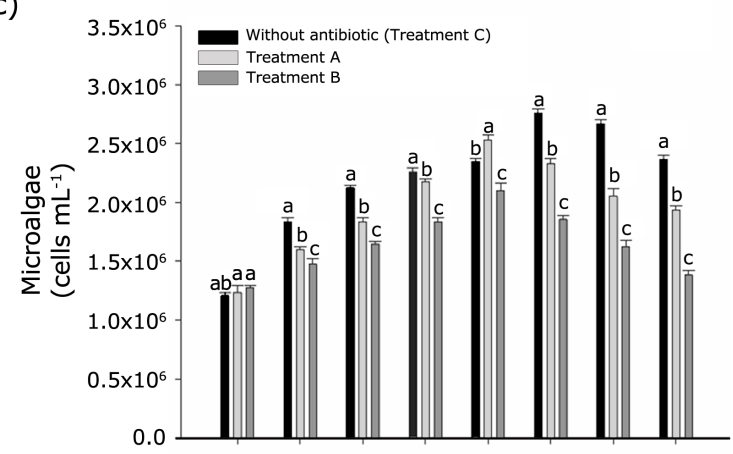

e)

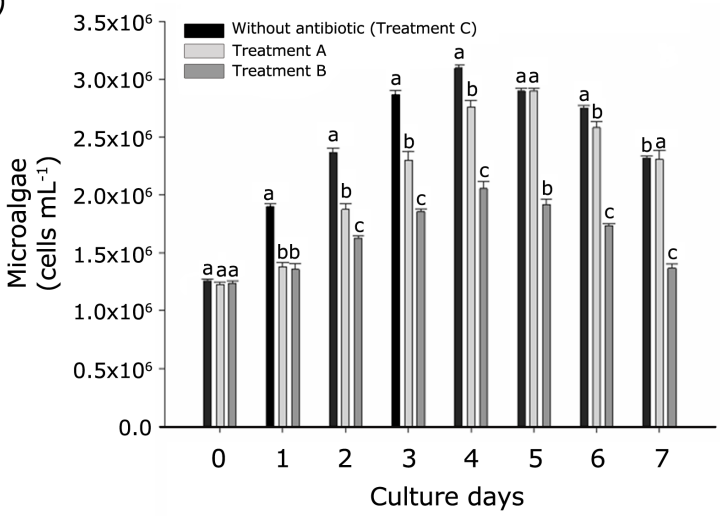

b)

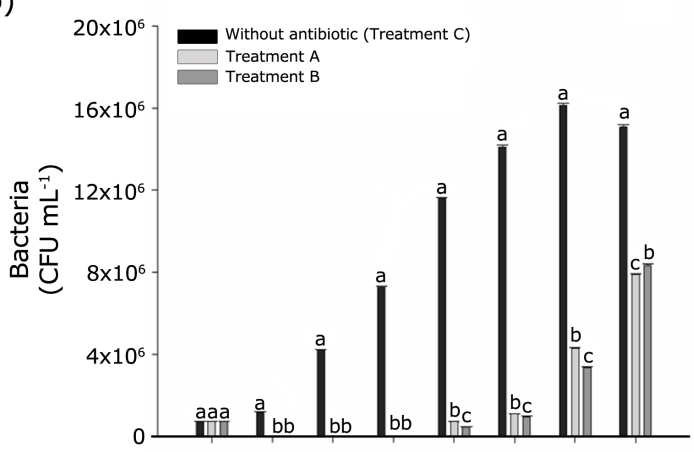

d)

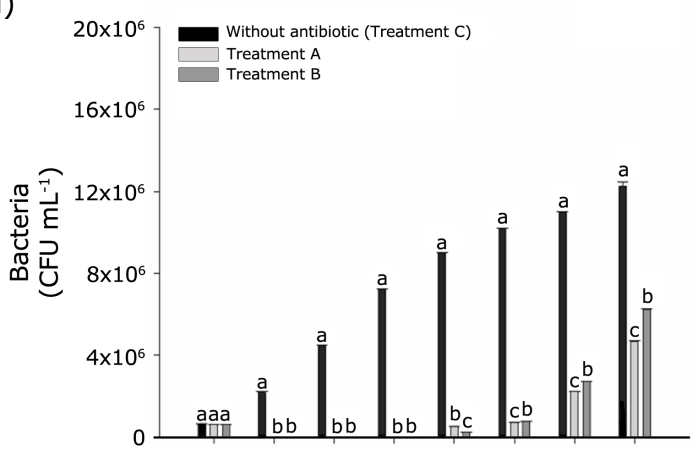

f)

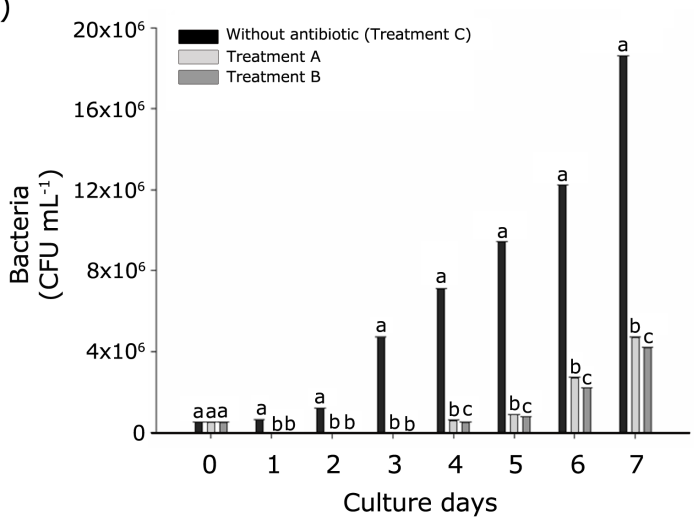

Figure 2. Mean values and standard deviation of cell concentration and heterotrophic bacteria load of monospecific batch cultures of Chaetoceros muelleri (a, b), C. calcitrans (c, d) and Chaetoceros sp. (e, f) maintained with three treatments (second assay). Treatment A: ampicillin ${ }^{\circledR} 250 \mu \mathrm{g} \mathrm{mL}{ }^{-1}$, kanamycin ${ }^{\circledR} 200 \mu \mathrm{g} \mathrm{mL}^{-1}$, neomycin ${ }^{\circledR} 50 \mu \mathrm{g} \mathrm{mL}^{-1}$, and streptomycin ${ }^{\circledR} 100 \mu \mathrm{g} \mathrm{mL}^{-1}$. Treatment B: ampicillin ${ }^{\circledast 5} 500 \mu \mathrm{g} \mathrm{mL}^{-1}$, kanamycin ${ }^{\circledR} 400 \mu \mathrm{g} \mathrm{mL}^{-1}$, neomycin ${ }^{\circledast} 100 \mu \mathrm{g} \mathrm{mL}^{-1}$, and streptomycin ${ }^{\circledast} 200 \mu \mathrm{g} \mathrm{mL}^{-1}$. Treatment C: culture without antibiotic addition (second assay). Different letters denote significant differences (one-way ANOVA $\boldsymbol{P}<0.05: \mathbf{a}>\mathbf{b}>\mathbf{c}$ ) / Valores promedio y desviación estándar de la concentración de células de Chaetoceros muelleri (a, b), C. calcitrans (c, d) y Chaetoceros sp. (e, f), y bacterias heterotróficas mantenidas con dos tratamientos. Tratamiento A: ampicilina ${ }^{\circledR} 250$

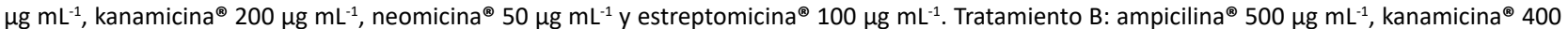
$\mu \mathrm{g} \mathrm{mL}^{-1}$, neomicina ${ }^{\circledast} 100 \mu \mathrm{g} \mathrm{mL}^{-1}$ y estreptomicina ${ }^{\circledR} 200 \mu \mathrm{g} \mathrm{mL}^{-1}$. Tratamiento C: cultivo sin adición de antibiótico (segundo ensayo). Letras diferentes denotan diferencias significativas (ANOVA de una vía $P<0,05$ : $a>b>c$ ) 
In the second assay, the lowest concentration mixture (treatment A) slightly diminished the cell concentration of the three Chaetoceros strain with respect to control treatment (Fig. 2). The heterotrophic bacterial load decreased significantly $(P<0.05)$ on the three diatom strains until day 3 , and then, slowly increased until day 7 .

The antibiotic mix with the highest concentration showed a significant decrease in cell concentration (10 to $30 \%$ ) for the three diatom strains throughout the culture time $(P<0.05)$ (Fig. 2). The heterotrophic bacterial load significantly decreased $(P<0.05)$ on the three diatom strains until day 3; after that, it slowly increased until day 7 with similar or lower bacterial load as described with the low concentration of the antibiotic mix.

\section{Discussion}

\section{Microalgae AND BaCterial GROWTH}

Microalgae cultures contain bacteria that interact with each other, associated with mechanisms that range from the production of compounds that inhibit or stimulate the growth of microalgae species. This type of interspecific relationship between species of bacteria-microalgae has been seen to depend on mutualism in many cases (Hernández-Pérez \& Labbé 2014, Clarke et al. 2019). The control of both bacterial and microalgal growth affects the growth, composition, and production of metabolites, and can result in great biotechnological benefits (Réveillon et al. 2016, Koedooder et al. 2019).

The cell concentration and growth rate measured on the cultures of $C$. muelleri were lower than those obtained by other authors (López-Elías et al. 2005, Pacheco-Vega \& Sánchez-Saavedra 2009, Orozco-Borbón et al. 2014), and the differences were due to the use of high culture volume, high temperature, and high cell concentration used as inoculum to the cultures. For $C$. calcitrans the growth rate was higher than the one obtained by Phatarpekar et al. (2000); meanwhile, cell concentration was lower than measured by Villa et al. (2014). For Chaetoceros sp., the cell concentration was lower than the concentration obtained by Sánchez-Saavedra \& Voltolina (2006) when the cultures were maintained with irradiance $60 \%$ higher than the irradiance used on this work.

The content of heterotrophic bacteria of the three Chaetoceros species used in this work increased proportionally as the cell concentration of the diatoms augmented. In $C$. muelleri cultures it has been described that the growth of heterotrophic bacteria rises directly proportionally as an increase in the cell concentration of the diatom throughout the culture time (Orozco-Borbon et al. 2014). These trends were previously described by other authors for different microalgae strains (Gomez-Gil et al. 2002, Ruiz-Güereca \& Sánchez-Saavedra 2016). For $C$. calcitrans, the heterotrophic bacteria content was

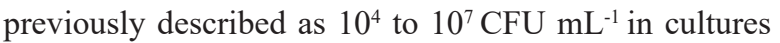
maintained in a commercial shrimp hatchery (LizárragaPartida et al. 1997).

In some cases, non-pathogenic bacteria can increase the growth of microalgae cultures such Nannochloropsis oculata, and C. calcitrans, which significantly increase their growth, when they are maintained in co-culture with Bacillus sp. and Pseudomonas sp. obtained from algae culture system (Sureshkumar et al. 2014). However, the impact of algal growth rates on the bacterial load in six microalgae species, shows that higher bacterial levels were associated with slow-growing microalgae on a per volume basis. The microalgae cultures can reach the contents of bacterial loads as 1 to $10^{8} \mathrm{CFU}$ per liter of culture (Murchelano \& Brown 1969). Variations on the bacterial load were more related to species. The higher contents of bacterial loads were associated with the Bacillariophyceae group reaching values between 5.7 to $16.4 \mathrm{CFU}$ algal cell ${ }^{-1}$, and for other microalgae species, the bacteria load was 0.2 to $4.3 \mathrm{CFU}$ algal cell-1 (Salvesen et al. 2000).

Bacterial growth rate was similar in all three Chaetoceros strains cultures. However, the density of the heterotrophic bacteria was higher with Chaetoceros sp., followed by the values measured with $C$. calcitrans, and $C$. muelleri. This difference in bacterial content between the three Chaetoceros species can be attributed to a species-specific interaction due to the specific extracellular products produced by each diatom species. In some cases, the bacterial content associated with different microalgae strains is related to the production of antibacterial substances, which are generally most abundant in slowgrowing microalgae cultures and the early stationary growth phase when the competition for nutrients is high due to abundance of both microalgae and bacteria (Borowitzka 1995). However, studies are needed to determine the chemical characterization of the compounds produced by each one of the Chaetoceros species and their associated bacteria.

The importance of maintaining monospecific microalgal cultures with low bacterial load is that the bacterial content can modify the growth characteristics and biochemical composition of the microalgal cells. Additionally, it is important to maintain cultures with low bacterial content or axenic cultures for studies such as genome sequencing (Vu et al. 2018, Pinder et al. 2019), interaction between species, harmful algal blooms, microalgae-bacteria consortia, cell cryopreservation, identification of bioactive compounds for biotechnology or pharmacology (Guillard 2005, Borowitzka 2013, Vu et al. 2018). 


\section{BACTERIAL LOAD REDUCTION ASSAYS}

The goal of purification methods is to obtain a viable culture of a single microalgal species, free of all other species (Guillard 2005).

In the first assay of this study, a lower content of heterotrophic bacteria in the monospecific cultures of Chaetoceros was obtained from the application of the antibiotic mix (treatment 4: ampicillin ${ }^{\circledR} 250 \mu \mathrm{g} \mathrm{mL}^{-1}$, kanamycin ${ }^{\circledR} 200 \mu \mathrm{g} \mathrm{mL}^{-1}$, neomycin ${ }^{\circledR} 50 \mu \mathrm{g} \mathrm{mL}^{-1}$ and streptomycin $\left.{ }^{\circledR} 100 \mu \mathrm{g} \mathrm{mL}^{-1}\right)$. This result is due to the interaction between the antibiotics used and the mechanism of action of each antibiotic, resulting in low concentration of bacteria and no apparent damage to the microalgae cells (Molina-Cárdenas et al. 2016).

The use of centrifugal washes, as well as the application of a single antibiotic, has been reported to have a low efficiency to achieve axenic cultures of several microalgae species (Wilkens \& Maas 2012). The disadvantage of using centrifugal washes is that the bacterial load of microalgae cultures is reduced for a very short time. It is mentioned that the use of different antibiotics must be specific to each microalgal species, depending on the characteristic bacterial community associated with the microalgae (Bruckner \& Kroth 2009). Centrifugation is perhaps a more frequently used method to concentrate the target organism rather than establishing unialgal cultures and avoiding bacteria contamination (Andersen \& Kawachi 2005, Molina et al. 2019).

According to the results obtained with three Chaetoceros species and with the use of the antibiotic mix in two different concentrations, a decrease in the content of heterotrophic bacteria (at levels not detectable for 4 days) was found. However, a reduction of the three Chaetoceros species growth (Fig. 2) was observed with the highest antibiotic concentration (treatment B).

The use of antibiotics must be strict and careful because it can increase the resistance in the populations of some bacterial species. Besides, it can affect the cell membrane and thereby inhibit microalgal growth, resulting in axenic cultures with average cell densities of $10^{6}$ cells $\mathrm{mL}^{-1}$ (González-Pleiter et al. 2013, Molina-Cárdenas et al. 2016). The use of a mixture of antibiotics as a control of bacteria in microalgae cultures shows synergistic effects that usually increase their toxicity to bacteria. However, some mixtures of antibiotics can produce a decrease in the microalgae population (González-Pleiter et al. 2013) or their concentrations, as observed in this study (second assay and treatment B).

Chlorotetracyclines and oxytetracyclines belong to tetracyclines, and are used as antibiotics for controlling Gram-positive and Gram-negative bacteria, mycoplasma, and viruses in the pig farming industry (Arsenakis
2018). These antibiotics act on the inhibition of protein synthesis and prevent the association of aminoacyl-t RNA and the ribosome of bacteria. Enrofloxacin is a broadspectrum quinolone that is widely used for the control of microorganisms (Guo \& Chen 2002). In microalgae, the main approach that has been given to studies related to the use of antibiotics is associated with B-lactams (ampicillin penicillin, chlortetracycline, and oxytetracycline), quinolones (norfloxacin, ciprofloxacin, and enrofloxacin) and macrolides (erythromycin). Our results demonstrate that the use of some antibiotics provided individually or in a mix, can decrease the bacterial load. Interestingly, the antibiotics significantly increase the cell concentration for C. muelleri cultures on days one to four. The positive effect of the mix of antibiotics to $C$. muelleri can be due to the cellular lysis of bacteria and that the cell components could be used by the diatom cells as nutrients, thus inducing cell production. The strains of $C$. calcitrans and Chaetoceros sp. do not show a growth-promoting effect due to the antibiotic mix. In some cases, the microalgae cells are resistant to some antibiotics at a determined concentration, period of exposure, culture conditions that can inhibit the effect of antibiotics and tolerance of some species of microalgae due to the physiological characteristics of the cells (Qunying \& Aiyi 2000, Guillard 2005). Penicillin could inhibit the growth of Phaeodactylum tricornutum and the inhibition decreased after five days. However, the use of penicillin increased the growth of Isochrysis sp., Isochrysis galbana and Platymonas subcordiformis. The use of streptomycin can inhibit the growth of Phaeodactylum tricornutum, Isochrysis sp., Isochrysis galbana, and Platymonas subcordiformis. The use of chloramphenicol inhibits the growth of Isochrysis sp. and Isochrysis galbana (Qunying \& Aiyi 2000). Some antibiotics act as growth promoters in agriculture due to the effect of lack of competition related to nutrients (Dibner \& Richards 2005).

The lethality of the antibiotic treatment in microalgae cultures is an intensity-time relationship, the intensity being the dose (concentration) of antibiotics and the time being the period of exposure before transfer to antibioticfree medium. The fundamental choice is which antibiotic to employ, at what concentration, and for how long. The action of a mixture of antibiotics is not, in general, the sum of individual actions (Guillard 2005). It was found that the three Chaetoceros species used in this work have different communities of bacteria, due to the different bacterial load throughout the culture time and to differences in susceptibility to decrease bacterial load or induce the growth of some diatom species. It has been found that the use of antibiotics to control bacterial growth in microalgal cultures - provided individually, in a binary mixture, or a mix - produces an inhibitory effect of various species of bacteria. However, the use of antibiotics is more effective in mixtures. In fact, there is a relationship between 
concentration, duration of treatment, and environmental factors, such as temperature and light (Carusso et al. 2018, Rico et al. 2018).

The importance of carrying out studies of axenization of microalgae species is, among others, to be used in genetic, transcriptomic, and microbiome studies, as well as in the study of the interrelation of bacteria and microalgae (Tapia et al. 2016, Severin \& Erdner 2019, Burgunter-Delamare et al. 2020).

In conclusion, it was found that the use of streptomycin produces bacterial load reduction on the three Chaetoceros species: $3 \%$ for C. muelleri, $17.5 \%$ for C. calcitrans, and $14 \%$ for Chaetoceros sp. When washing with sterile seawater was used, heterotrophic bacteria decreased nearly $50 \%$ in the three Chaetoceros cultures. The use of sulfate $\mathrm{G} 41{ }^{\circledR}$ produces a reduction of bacterial load of $18 \%$ for C. muelleri, $33 \%$ for C. calcitrans, and $24 \%$ for Chaetoceros sp. The most effective treatment was the use of an antibiotic mix composed of ampicillin $\AA(250 \mu \mathrm{g} \mathrm{mL}-$ $\left.{ }^{1}\right)$, kanamycin $\AA\left(200 \mu \mathrm{g} \mathrm{mL}^{-1}\right)$, neomycin $\left(20 \mu \mathrm{g} \mathrm{mL}^{-1}\right)$, and streptomycin ${ }^{\circledR}\left(100 \mu \mathrm{g} \mathrm{mL}^{-1}\right)$, because this antibiotic mixture induces a reduction of bacterial load (100\%) in the three Chaetoceros species from day one to day three. The growth rate of the diatoms was slightly reduced with respect to the control treatment. The mix prepared with the high antibiotic concentration produced a reduction of bacterial load (100\%) for three days; however, it also generated a significant reduction of Chaetoceros growth (10 to $30 \%$ ).

\section{ACKnowledgments}

This work was supported by Centro de Investigación Científica y de Educación Superior de Ensenada (CICESE, Projects, 623108, 823801 and 623115). We would like to thank Consejo Nacional de Ciencia y Tecnología (CONACyT) for the scholarship for postgraduate studies of the first author and the postgrad program of the aquaculture Department, CICESE for the scholarship that allowed the first author to write this manuscript. Finally, we thank the anonymous reviewers, for the excellent comments on the paper.

\section{LITERATURE CITED}

Andersen RA \& M Kawachi. 2005. Traditional microalgae isolation techniques. In: Andersen RA(ed). Algal culturing techniques, pp. 83-100. Elsevier, Amsterdam.

Arsenakis I. 2018. Different vaccination protocols with bacterins as a means to control Mycoplasma hyopneumoniae infections in peri-weaned and fattening pigs. Doctoral Dissertation, Faculty of Veterinary Medicine, Ghent University, Merelbeke, 120 pp. <https://biblio.ugent.be/ publication/8580864>
Borowitzka MA. 1995. Microalgae as source of pharmaceuticals and other biologically active compounds. Journal of Applied Phycology 7: 3-15.

Borowitzka MA. 2013. High value production from microalgae their development and commercialization. Journal of Applied Phycology 25: 743-756.

Bozarth A, UG Maier \& S Zauner. 2009. Diatoms in biotechnology: modern tools and applications. Applied Microbiology and Biotechnology 82(2): 195-201.

Bruckner CG \& PG Kroth. 2009. Protocols for the removal of bacteria from freshwater benthic diatom cultures. Journal of Phycology 45(4): 981-986.

Burgunter-Delamare B, H Kleinjan, C Frioux, E Fremy, M Wagner, E Corre, A Le Salver, C Leroux, C Leblanc, C Boyen, A Siegel \& SM Dittami. 2020. Metabolic complementarity between a brown alga and associated cultivable bacteria provide indications of beneficial interactions. Frontiers in Marine Science 7: 85. $<$ https:// doi.org/10.3389/fmars.2020.00085>

Carusso S, AB Juárez, J Moretton \& A Magdaleno. 2018. Effects of three veterinary antibiotics and their binary mixtures on two green alga species. Chemosphere 194: 821-827.

Cho DH, R Ramanan, BH Kim, J Lee, S Kim \& C Yoo. 2013 Novel approach for the development of axenic microalgae cultures from environmental samples. Journal of Phycology 49: $802-810$

Choi GG, MS Bae, CY Ahn \& HM Oh. 2008. Induction of axenic culture of Arthrospira (Spirulina) platensis based on antibiotic sensitivity of contaminating bacteria. Biotechnology Letters 30(1): 87-92.

Clarke AK, ON Johansson, MI Pinder, F Ohlsson, J Egardt \& M Töpel. 2019. Friends with benefits: Exploring the phycosphere of the marine diatom Skeletonema marinoi. Frontiers in Microbiology 10: 1828. <https://doi. org/10.3389/fmicb.2019.01828>

Dibner JJ \& JD Richards. 2005. Antibiotic growth promotors in agriculture: history and mode of action. Poultry Science 84(4): 634-643.

Duff DC, DL Bruce \& NJ Anita. 1966. The antibacterial activity of marine phytoplankton algae. Canadian Journal of Microbiology 12: 877-884.

Fogg GE \& BJ Thake. 1987. Algal cultures and phytoplankton ecology, 269 pp. University of Wisconsin Press, London.

Gerhardt P, RGE Murray, RN Costilow, EW Nester, WA Good, NR Krieg \& GB Phillips. 1981. Manual of methods for general bacteriology, $524 \mathrm{pp}$. American Society for Microbiology, Washington DC.

Gomez-Gil B, A Roque \& G Velasco-Blanco. 2002. Culture of Vibrio alginolyticus $\mathrm{C} 7 \mathrm{~b}$, a potential probiotic bacterium, with the microalga Chaetoceros muelleri. Aquaculture 211(1-4): 43-48

González-Pleiter M, S Gonzalo, I Rodea-Palomares, F Leganés, R Rosal, K Boltes \& F Fernández-Piñas. 2013. Toxicity of five antibiotics and their mixtures towards photosynthetic aquatic organisms: implications for environmental risk assessment. Water Research 47(6): 2050-2064. 
Guillard RRL. 2005. Purification methods for microalgae. In: Andersen RA (ed). Algal culturing techniques, pp. 117-132. Elsevier, London.

Guillard RRL \& JH Ryther. 1962. Studies on marine planktonic diatoms I. Cyclotella nana Hustedt and Detonula confervacea (Cleve) Gran. Canadian Journal of Microbiology 8: 229-239.

Guiry MD \& GM Guiry. 2021. AlgaeBase. World-wide electronic publication, National University of Ireland, Galway. <http://www.algaebase.org $>$

Guo RX \& JQ Chen. 2012. Phytoplankton toxicity of the antibiotic chlortetracycline and its UV light degradation products. Chemosphere 87(11): 1254-1259.

Han PP, SR Jia, Y Sun, ZL Tan, C Zhong, Y Dai, N Tan \& SG Shen. 2014. Metabolomic approach to optimizing and evaluating antibiotic treatment in the axenic culture of cyanobacterium Nostoc flagelliforme. World Journal of Microbiology and Biotechnology 30(9): 2407-2418.

Hernández-Peréz A \& JI Labbé. 2014. Microalgas cultivo y beneficios. Revista de Biología Marina y Oceanografía 48(2): 157-173.

Ishii KI, I Imai, M Natsuike, S Sawayama, R Ishino, W Liu, K Fokusaki \& A Ishikawa. 2018. A simple technique for establishing axenic cultures of centric diatoms from resting stage cells in bottom sediments. Phycologia 57(6): 674-679.

Johansson ON, MI Pinder, F Ohlsson, J Egardt, M Töpel \& AK Clarke. 2019. Friends with benefits: Exploring the phycosphere of the marine diatom Skeletonema marinoi. Frontiers in Microbiology 10:1828. <doi: 10.3389/ fmicb.2019.01828>

Jones AK, ME Rhodes \& SC Evans. 1973. The use of antibiotics to obtain axenic cultures of algae. British Phycological Journal 8(2): 185-196.

Koedooder C, W Stock, A Willems, S Mangelinckx, M De Troch, W Vyverman \& K Sabbe. 2019. Diatom-bacteria interactions modulate the composition and productivity of benthic diatom biofilms. Frontiers in Microbiology 10: 1255. <https://doi.org/10.3389/fmicb.2019.01255>

Kumaran J, B Jose, V Joseph \& IS Bright-Singh. 2017. Optimization of growth requirements of marine diatom Chaetoceros muelleri using response surface methodology. Aquaculture Research 48(4): 1513-1524.

Lee HG, SY Shin, L Jin, C Yoo, A Srivastava, HJ La, CY Ahn, HS Kim \& HM Oh. 2015. Establishment and maintenance of an axenic culture of Ettlia sp. using a species-specific approach. Biotechnology and Bioprocess Engineering 20(6): 1056-1063.

Leynaert A, C Fardel, B Beker, C Soler, G Delebecq, A Lemercier, P Pondaven, PE Duran \& K Heggarty. 2018. Diatom frustules nanostructure in pelagic and benthic environments. Silicon 10(6): 2701-2709.

Lizárraga-Partida ML, L Montoya-Rodríguez \& V Gendrop-Funes. 1997. The use of bacterial counts in two Mexican shrimp hatcheries. Ciencias Marinas 23: 129-140.

López-Elías JA, D Voltolina, F Enríquez-Ocaña \& G Gallegos-Simental. 2005. Indoor and outdoor mass production of the diatom Chaetoceros muelleri in a Mexican commercial hatchery. Aquacultural Engineering 33(3): 181-191.
Qunying LQW \& Z Aiyi. 2003. The effect of antibiotics on the growth and restoration of marine microalgae. Journal of Zhejiang Ocean University 3. <http://en.cnki.com.cn/ Article_en/CJFDTotal-REEF200003009.htm>

Milagros R, AV Franco, HP Igcasan, MDGN Arnaldo, RM Piloton, SS Garibay \& VT Balinas. 2018. Microalgal paste production of the diatom Chaetoceros calcitrans using electrolytic flocculation method at optimum culture conditions. Aquaculture International 26(4): 1119-1134.

Molina D, JC de Carvalho, AIM Júnior, C Faulds, E Bertrand \& CR Soccol. 2019. Biological contamination and its chemical control in microalgal mass cultures. Applied Microbiology and Biotechnology 103(23-24): 9345-9358.

Molina-Cárdenas CA, MP Sánchez-Saavedra \& AF Licea-Navarro. 2016. Decreasing of bacterial content in Isochrysis galbana cultures by using some antibiotics. Revista de Biología Marina y Oceanografía 51(1): 101-112.

Murchelano RA \& C Brown. 1969. Bacterial flora of some algal food used for rearing bivalve larval. Journal of Fisheries Research Board of Canada 32: 739-745.

Nagai S, I Imai \& T Manabe. 1998. A simple and quick technique for establishing axenic cultures of the centric diatom Coscinodiscus wailesii Gran. Journal of Plankton Research 20(7): 1417-1420.

Orozco-Borbón MV, E Valenzuela-Espinoza \& JC GarcíaLópez. 2014. Simultaneous growth of Chaetoceros muelleri and bacteria in batch cultures. Advances in Microbiology 4(15): 1025. <doi: 10.4236/aim.2014.415113>

Pacheco-Vega JM \& MP Sánchez-Saavedra. 2009. The biochemical composition of Chaetoceros muelleri (Lemmermann Grown) with an agricultural fertilizer. Journal of the World Aquaculture Society 40(4): 556-560.

Phatarpekar PV, RA Sreepada, C Pednekar \& CT Achuthankutty. 2000. A comparative study on growth performance and biochemical composition of mixed culture of Isochrysis galbana and Chaetoceros calcitrans with monocultures. Aquaculture 181(1-2): 141-155.

Pinder MI, ON Johansson, AAlmstedt, O Kourtchenko, AK Clarke, A Godhe \& M Töpel. 2019. Genome sequence of Kordia sp. strain SMS9 identified in a non-axenic culture of the diatom Skeletonema marinoi. Journal of Genomics 7: 46. < doi: 10.7150/jgen.35061>

Réveillon D, V Séchet, P Hess \& Z Amzil. 2016. Production of BMAA and DAB by diatoms (Phaeodactylum tricornutum, Chaetoceros sp., Chaetoceros calcitrans and, Thalassiosira pseudonana) and bacteria isolated from a diatom culture. Harmful Algae 58: 45-50.

Rico A, W Zhao, F Gillissen, M Lürling \& PJ Van den Brink. 2018. Effects of temperature, genetic variation and species competition on the sensitivity of algae populations to the antibiotic enrofloxacin. Ecotoxicology and Environmental Safety 148: 228-236.

Ruiz-Güereca DA \& MP Sánchez-Saavedra. 2016. Growth and phosphorus removal by Synechococcus elongatus coimmobilized in alginate beads with Azospirillum brasilense. Journal of Applied Phycology 28(3): 1501-1507. 
Salvesen I, KI Reitan, GJ Skjermo \& G Øie. 2000. Microbial environments in marine larviculture: impacts of algal growth rates on the bacterial load in six microalgae. Aquaculture International 8(4): 275-287.

Sánchez-Saavedra MP \& D Voltolina. 1995. The effect of different light quality on the food value of the diatom Chaetoceros sp. for Artemia franciscana Kellogg. Rivista Italiana di Acquacoltura 30: 135-138.

Sánchez-Saavedra MP \& D Voltolina. 2001. Changes in the chemical composition of the diatom Chaetoceros sp. during use as food for filter-feeders. Rivista Italiana di Acquacoltura 36: 53-58.

Sánchez-Saavedra MDP \& D Voltolina. 2006. The growth rate, biomass production and composition of Chaetoceros sp. grown with different light sources. Aquacultural Engineering 35(2): 161-165.

Sena L, D Rojas, E Montiel, H González, J Moret \& L Naranjo. 2011. A strategy to obtain axenic cultures of Arthrospira spp. cyanobacteria. World Journal of Microbiology and Biotechnology 27: 1045-1053.

Severin T \& DL Erdner. 2019. The phytoplankton taxondependent oil response and its microbiome: correlation but not causation. Frontiers in Microbiology 10: 385. <https:// doi.org/10.3389/fmicb.2019.00385>

Sureshkumar S, B Jasmin, KM Rahiman \& AH Mohammed. 2014. Growth enhancement of microalgae Chaetoceros calcitrans and Nannochloropsis oculata using selected bacterial strains. International Journal of Current Microbiology and Applied Sciences 3(4): 352-359.

Tapia JE, B González, S Goulitquer, P Potin \& JA Correa. 2016. Microbiota influences morphology and reproduction of the brown alga Ectocarpus sp. Frontiers in Microbiology 7: 197. <https://doi.org/10.3389/fmicb.2016.00197>
Tapia-Gallardo YD. 2019. Análisis genómico y desempeño de cultivos axénicos de tres especies de la microalga Chaetoceros. Tesis de Maestría, Centro de Investigación Científica y de Educación Superior de Ensenada (CICESE), Ensenada, 112 pp.

Trujillo-Valle ML. 1993. La colección de microalgas del CICESE, 103 pp. Informe Técnico. Comunicaciones Académicas, Serie Acuicultura, Centro de Investigación Científica y de Educación Superior de Ensenada (CICESE), Ensenada, $103 \mathrm{pp}$.

Villa A, D Herazo \& AC Torregroza. 2014. Efecto del fotoperiodo sobre el crecimiento de la diatomea Chaetoceros calcitrans (clon c-cal) en cultivos estáticos. Intropica 9: 111-117.

Vu CHT, H-G Lee, YK Chang \& H-M Oh. 2018. Axenic cultures for microalgal biotechnology: establishment, assessment, maintenance, and applications. Biotechnology Advances 36(2): 380-396.

Wilkens SL \& EW Maas. 2012. Development of a novel technique for axenic isolation and culture of thraustochytrids from New Zealand marine environments. Journal of Applied Microbiology 112(2): 346-352.

Zakharova Y, A Marchenkov, N Volokitina, A Morozov, Y Likhoshway \& M Grachev. 2020. Strategy for the removal of satellite bacteria from the cultivated Diatom. Diversity 12(10): 382-394.

ZoBell CE. 1941. Studies on marine bacteria. I. The cultural requirements of heterotrophic aerobes. Journal of Marine Research 4(1): 42-75. 